\title{
Antecedent and Consequent Analysis of Entrepreneurial Orientation in Students of Faculty of Economics and Business Trisakti University
}

\author{
Ellyana Amran ${ }^{1}$, Aina Zahra Parinduri ${ }^{2}$ \\ \{ellyana_amran@trisakti.ac.id ${ }^{1}$, ainaparinduri@trisakti.ac.id² \\ Faculty of Economics and Business Universitas Trisakti, Jakarta, Indonesia ${ }^{1,2}$
}

\begin{abstract}
The role of entrepreneurship in the economy is an important economic driver by fostering entrepreneurial spirit, which can be trusted as a solution to limited job opportunities and reducing poverty. This study aims to explain the effect of entrepreneurship education on interest in entrepreneurship which is mediated by the entrepreneurial orientation of FEB Trisakti University students. Sampling using purposive sampling technique, total 288 respondents. The study used a quantitative approach, data was collected using the Structural Equation Model (SEM) methodology. The research findings are that there is a positive effect of entrepreneurship education on entrepreneurship orientation; entrepreneurial orientation has a positive influence on interest in entrepreneurship; there is no influence of entrepreneurship education on interest in entrepreneurship; and there is a positive influence of entrepreneurship education on interest in entrepreneurship indirectly through entrepreneurship orientation.
\end{abstract}

Keywords: Entrepreneurship Education; Entrepreneurial Intention; Entrepreneurial Orientation

\section{Introduction}

Entrepreneurship is believed to be an important force in the global economic growth that creates new businesses as an absorber of labour. Entrepreneurship education is perceived and recognized as a helpful support that fosters entrepreneurial spirit, especially in helping to change mindset of younger generation who intend to be job seekers following their education completion [1]. The involvement of universities in entrepreneurship empowerment programs is described in Government Regulation of the Republic of Indonesia No. 60 of 1999 article 3 paragraph 1. Entrepreneurship education is an initial capital that can shape student's selfesteem based on various skills and characters, ranging from the ability to think multidimensional to the ability to identify new opportunities and to implement new ideas into practice [2]. Entrepreneurship education is seen as a solution that can help solve the country's economy from the challenges of poverty and unemployment [3].

Ironically, the number of young entrepreneurs in Indonesia is still considered as low, only $0.18 \%$ of entrepreneurs or approximately around 400 thousands out of 220 million people [4]. 
The number of young entrepreneurs in Indonesia in proportion to the total number of the country's population is still far compared to developing countries such as United States of America (11.5\%), Singapore (7.2\%), and Malaysia (5\%). A country is considered as prosper when they reach at least $2 \%$ of its population identify as entrepreneurs. There is still a lot gaps in the knowledge of Indonesian people that assumes entrepreneurship is a born talent, where majority of people is not convinced that entrepreneurship can be fostered through education due to its attitudinal and behavioural. While entrepreneurship is an intended and planned behavior. As the demand of the new age continues, the involvement of higher education institution in entrepreneurship education is necessary. Because, without entrepreneurship education and training, it will not be possible to drive the entrepreneurial spirit in individuals.

Experience and knowledge of entrepreneurship is very important to be considered as a factor that determines interest in entrepreneurship. [5] explains, based on entrepreneurship theory, there is a clear relationship between education or entrepreneurial knowledge with ideas and intentions to start a new business. That is why many universities include entrepreneurship courses in their curriculum. The goal is none other than to increase the entrepreneurial interest of potential entrepreneurs. Understanding of the student's entrepreneurship interest, the faculty will be able to facilitate what students need and want, as well as provide advice and consultation regarding business or business that can be tailored to their respective interests and potential. A common phenomenon that still continues is the role of the campus that is found to be not optimal to create a culture of entrepreneurship [6]. This is proven by the lack of innovation for the industry that comes from universities. It is also supported by the claim of [7] that reveals that most college graduates, both business and non-business majors, have no interest in becoming entrepreneurs. However, this is not a particular guarantee, that elite university graduates find jobs easily and "safely", because one has to compete for jobs that are increasingly scarce in availability.[8], [9].

In the learning process of the Entrepreneurship Education course at the Faculty of Economics and Business, Trisakti University, students are directed to have a future-oriented thinking, in line with one of the goals, namely to produce graduates who are independent, creative, innovative, develop an entrepreneurial spirit who have social sensitivity, and have global competitiveness. The Faculty of Economics and Business has three undergraduate study programs, namely Development Economics, Management and Accounting. The role of the lecturer as a facilitator is important, which includes the transfer of knowledge, transfer of skills and transfer of attitude. It is expected that lecturers can grow their intentions and are ready to build a career as an entrepreneur with the provision of entrepreneurship education while studying at the faculty.

The purpose of this paper is to present and develop the antecedents and consequences of business orientation, as economic reforms and the need for better infrastructure lead to entrepreneurial development programs. Additionally, entrepreneurship is highly pursued and accepted by developing countries in the world with the same spirit as the main engine that drives the economy, innovation and competitiveness [10]. The paper is structured as follows: Part 1 is an introduction, followed by theories and hypotheses in Part 2; Section 3 is a methodology related to the details of the instruments used to collect data and technical data analysis followed by the results in Section 4; The paper concludes with the research limitations and implications in Sections 5 and 6. In this qualitative data, Entrepreneurial Education (EE) is independent variable which has 5 indicators, Entrepreneurial Orientation (EO) is mediating variable and dependent variable is Entrepreneurial Intention (EI), also has 5 indicators. 


\section{Theoretical Framework and Hypothesis Development}

\subsection{Theoretical Framework}

In this qualitative data, Entrepreneurial Education (EE) is independent variable which has 5 indicators, Entrepreneurial Orientation (EO) is mediating variable and dependent variable is Entrepreneurial Intention (EI), also has 5 indicators.

Table 1. The operational variables are as follows

\begin{tabular}{|c|c|c|}
\hline No & Variables & Indicators \\
\hline 1 & $\begin{array}{l}\text { Entrepreneurship Education }(\mathrm{X}) \text { : is } \\
\text { learning process to change students' } \\
\text { attitude and mindset } \\
{[11],[12] \text {. }}\end{array}$ & $\begin{array}{l}\text { X1 (Entrepreneurship Material) } \\
\text { X2 (Learning Method) } \\
\text { X3 (Entrepreneurial Skills) } \\
\text { X4 (Facilitator) } \\
\text { (X5 Entrepreneurial Program) }\end{array}$ \\
\hline 2 & $\begin{array}{l}\text { Entrepreneurial Orientation (Y) : } \\
\text { attitude that must be owned by an } \\
\text { entrepreneur-related to the survival of } \\
\text { the company. } \\
\text { [13] }\end{array}$ & $\begin{array}{l}\text { Y1 (Autonomy) } \\
\text { Y2 (Innovation) } \\
\text { Y3 (Pro-activeness) } \\
\text { Y4 (Risk Taking) } \\
\text { Y5 (Aggressive in Competition) }\end{array}$ \\
\hline 3 & $\begin{array}{l}\text { Entrepreneurial Intention: }(Z): \text { is the } \\
\text { desire of students to be independent or } \\
\text { to run their own business. } \\
{[14],[15]}\end{array}$ & $\begin{array}{l}\text { Z1 (Self-efficacy) } \\
\text { Z2 (Motivation) } \\
\text { Z3(Helping the social environment) } \\
\text { Z4 (Leadership) } \\
\text { Z5 (Access of capital) }\end{array}$ \\
\hline
\end{tabular}

\subsection{Hypothesis development}

\section{Entrepreneurship education and Entrepreneurial Orientation}

Entrepreneurship education is important, especially for the younger generation, because the educational program is designed to competition, skills and values needed in recognizing business opportunities, organizing and starting businesses. create jobs and be able to compete globally [16], [17]. Learning methods are not only in the form of knowledge and skills related to the concept of entrepreneurship, but also the ability to form attitudes, behaviours, mindset and the ability to realize a real business [18]. The community plays a role in creating independent entrepreneurial development. The development of cultural values and improvements in entrepreneurship education is the key to developing entrepreneurial passion and spirit. Becoming an entrepreneur is a learning outcome. Even though there is talent from birth, the entrepreneurial spirit must be honed and motivated in the learning process, like a knife if it is sharpened continuously [19]. Entrepreneurship education does not only provide theoretical knowledge, but is also expected to influence behavior and mindset on how to become a successful entrepreneur in the future so that it can open up new job opportunities [18], [20]. If efforts to instill an entrepreneurial spirit and spirit in higher education continue to be appropriately promoted, an entrepreneurial orientation will grow within them. Entrepreneurial orientation refers more to processes, practices and decision making in entrepreneurial activities, namely independence, courage to take risks, proactively innovative 
towards business opportunities and having an aggressive attitude in competing [21]. This statement is in line with research [22], [23] where these five processes must continue to be ingrained so as to form the personality of an entrepreneur. The end result of his ability related to entrepreneurial orientation will increase entrepreneurial intention, which encourages business performance to increase. Entrepreneurship education is considered effective, if students as learning participants have an entrepreneurial orientation, which is increasingly honed in terms of innovation, independence, has a high sense of sensitivity to problems that exist in the surrounding environment, dares to take risks which are characteristics of entrepreneurs. This is supported by research proposed by [24]. Based on previous research, the proposed hypothesis development is:

H1: Entrepreneurship Education has a positive effect on Entrepreneurial Orientation in FEB Usakti Students

\subsection{Entrepreneurial Orientation and Entrepreneurial Intention}

Entrepreneurial Orientation (EO) refers to processes, practices and decision making that encourage entrepreneurial activities, which can be measured through the ability to innovate and be creative, proactive attitude towards business opportunities, aggressive in competition, dare to take risks and have the independence to start a business [13], [15], [25]. As a result, it is believed that individuals with entrepreneurial spirit that tends to intend to run a business. Therefore, entrepreneurial orientation is a determining factor to become an entrepreneur [21]. In this case, there is a positive relationship with entrepreneurial intention.

These individual traits are more open to new things and generate creative ideas. Individuals with the ability to innovate tend to have high self-confidence in achieving the success of their ideas. Likewise, those who are highly proactive, have the ability to manage resources and make decisions .[26]. And creative and innovative individuals are very proactive about business opportunities. And this shows the tendency of a fairly large entrepreneurial intention [27]. In turn, individuals who dare to take risks in the sense of not being afraid of failure also show that they have great entrepreneurial intentions, compared to individuals who avoid risk, because they are more confident in their abilities in running their business [28]. Of course, it is very important to be able to develop individuals who are not only able to create new businesses, but also have the ability to identify and generate existing opportunities. The biggest obstacle that stands in the way of entrepreneurial intentions and business creation is the fear of failure in entrepreneurship. So it can be said that this entrepreneurial orientation is a strategy in making entrepreneurial decisions and actions [29]. So based on the above review, the proposed hypothesis is:

$\mathrm{H} 2$ : Entrepreneurial Orientation has a positive effect on Entrepreneurial Intentions in FEB Usakti Students

\subsection{Entrepreneurial Education and Entrepreneurial Intention}

Entrepreneurship education is a conscious effort made by individuals to add insight into entrepreneurship [30]. If entrepreneurship education is carried out properly through curriculum and entrepreneurship training programs, it will foster the interest and love of students in the world of entrepreneurship. Besides that, entrepreneurship education is more about learning skills, it is also necessary to study one's experiences as an attitude development to become an entrepreneur [19]. And this is the biggest challenge felt by universities to make appropriate entrepreneurship education curriculum and training programs feasibility [31]. Of 
course entrepreneurship education is an important thing, especially for the younger generation, because it fosters and develops entrepreneurial passion, spirit and behaviour that enables them to become job creators [32], [33]

Entrepreneurial intention is an individual's desire to start a business [34]. This opinion is further strengthened that the choice to become an entrepreneur must be followed by commitment, which requires preparation at the time of starting [35]. Therefore, entrepreneurial intention has been proven to be a predictor of entrepreneurial behaviour and is used as a basic approach to understanding who will become entrepreneurs [36]. Entrepreneurship education will be able to foster student interest in choosing entrepreneurship as a career choice. [37]. Intention can also be described how strong the motivation to try and do the business that has been planned. In this case there is an attempt to find information related to the business that will be undertaken. The higher a person's intention to become an entrepreneur, the greater the probability of success in achieving their business goals [38]. Based on previous research, the proposed hypothesis development is:

H3: Entrepreneurship Education has a positive effect on Entrepreneurial Intention in FEB Usakti Students

\subsection{Entrepreneurship Education, Entrepreneurial Intention and Entrepreneurship Orientation}

Entrepreneurship Education is a process of providing structured and formal entrepreneurial competencies covering skills, concepts and individual mental awareness [39]. This entrepreneurial learning process can shape the entrepreneurial orientation of students on the ability to innovate, be proactive about business opportunities, the ability to take risks, be independent and aggressive in competition [13], [15]. As a result, they tend to have business behaviour such as tending to start a business, have innovation, be proactive and dare to take risks [40]. Sulistorini in his findings said that entrepreneurship education has not been able to foster an entrepreneurial orientation, most of the students after graduation they prefer to be job seekers, they prefer to avoid risk, because there is a fear of failure. Of course this is an obstacle to the intention of creating a business. (http://admisibisnis.blogspot.com/2013/07/method-pembelajaran-kewirausahaan). Therefore, it is a challenge for universities to design comprehensive and integrated entrepreneurship education programs and activities, that can facilitate the growth of entrepreneurial intentions of each student. In addition, there needs to be strong support from the family [41]. Based on previous research, the proposed hypothesis development is:

H4: Entrepreneurship Education has a positive effect on Entrepreneurial Intentions of Entrepreneurial Orientation in FEB Usakti Students which is mediated by entrepreneurship orientation.

\section{Research Methodology}

This study uses quantitative methods with survey techniques, where primary data is obtained directly from respondents by distributing questionnaires through online internet media. Each indicator is measured by a Likert scale with a scale of 1 to 5 . Hypothesis testing using the technical analysis of Structural Equation Model (SEM) using AMOS 22. The research population is FEB students, total 800 people. The minimum number of samples that represent the population is determined by the criteria of 5-10 times the number of indicators 
(Ferdinand, 2000) and the ideal sample for Maximum Likelihood (MLE) research is recommended 100-400, so the sample range of this study is $75-400$ samples. In order to obtain more accurate results and represent the population, the number of samples taken was 288 samples, using the purposive sampling method, in which there were considerations in sampling, namely: 1) active students who were taking entrepreneurship courses in even semesters; 2) between the ages of 19 - 24 years.

Validity test is used to measure whether the questionnaire is valid if the question in it were able to reveal something that will be measured in the questionnaire. Validity test can be done by comparing of $p$-value with significance level of 5 percents. If $p$-value $<0.05$ then the questions or indicators is valid, if If p-value $\geq 0.05$ then the questions or indicators is not valid. Reliability test is tool that can be used to measure a questionnaire which indicators of the variables by using Cronbach's Alpha. A questionnaire is reliable if the answers are consistent. A variable is reliable if the value of Cronbach's Alpha is $>0.6$ [42]. In general, it is summarized that the structural model of this research fits the criterial of existing indicator, where the acquired hypothesis analysis fits the proposed research method.

\section{Result and Discusion}

Characteristics of research respondents consisted of $31.9 \% \mathrm{~b}$ (92 people) were men and the remaining $68.1 \%$ (196 people) were women. $44.4 \%$. $86 \%$ of respondents are in the range of $18-22$ years. The Study Program (Prodi) is dominated by Accounting Study Program which is $55.6 \%$ (160 people), Management Study Program by $21.2 \%$ (61 people) and lastly the Development Economics Study Program $18.1 \%$ or 52 people.

Table 2. Instrument Validation Test Result

\begin{tabular}{cccccc}
\hline No & Variable & Indicator & $\begin{array}{c}\text { Correlation } \\
\text { Coefficient }\end{array}$ & p-value & Decision \\
\hline 1 & Entrepreneurship Education (X) & X1 & 0.830 & 0.000 & Valid \\
& & X2 & 0.861 & 0.000 & Valid \\
& & X3 & 0.810 & 0.000 & Valid \\
& & X4 & 0.718 & 0.000 & Valid \\
& & X5 & 0.768 & 0.000 & Valid \\
& \multirow{4}{*}{ Entrepreneurial Orientation (Y) } & Y1 & 0.747 & 0.000 & Valid \\
& & Y2 & 0.646 & 0.000 & Valid \\
& & Y3 & 0.828 & 0.000 & Valid \\
& & Y4 & 0.833 & 0.000 & Valid \\
& & Y5 & 0.717 & 0.000 & Valid \\
& \multirow{4}{*}{ Entrepreneurial Orientation (Z) } & ZI & 0.656 & 0.000 & Valid \\
& & Z2 & 0.621 & 0.000 & Valid \\
& & Z3 & 0.790 & 0.000 & Valid \\
& & Z4 & 0.792 & 0.000 & Valid \\
& & Z5 & 0.802 & 0.000 & Valid \\
\hline
\end{tabular}

Table 2 show that the correlation between each indicators to total construct score in each variable shows significant result and show that $\mathrm{p}$-value $<0.05$, which interpret that the data result for all variables are valid 
Table 3. Instrument Reliability Test Result

\begin{tabular}{clccc}
\hline No & \multicolumn{1}{c}{ Variable } & Number of Statement Items & Cronbach's Alpha & Decision \\
\hline 1. & Entrepreneurship Education (X & 5 & 0.856 & Reliable \\
2. & Entrepreneurial Orientation (Y) & 5 & 0.808 & Reliable \\
3. & Entrepreneurial Intention (Z) & 5 & 0.773 & Reliable \\
\hline
\end{tabular}

Table 3 show that the Cronbach's Alpha resulted in this research is more than 0,6 means the result of the data is considered reliable.

Table 4. Test Results Significant Structural Model Research

\begin{tabular}{|c|c|c|c|c|}
\hline Hypothesis & Hypothesis Statement & Effect & $\mathbf{P}$ & Decision \\
\hline $\mathrm{H} 1$ & $\begin{array}{l}\text { Entrepreneurship Education } \rightarrow \\
\text { Entrepreneurial Orientation }\end{array}$ & 0.671 & 0.000 & $\begin{array}{l}\text { Positive, significant, } \\
\text { data supports the } \\
\text { research model }\end{array}$ \\
\hline $\mathrm{H} 2$ & $\begin{array}{l}\text { Entrepreneurial Orientation } \rightarrow \\
\text { Entrepreneurial Intention }\end{array}$ & 0.777 & 0.000 & $\begin{array}{l}\text { Positive, significant, } \\
\text { data supports the } \\
\text { research model }\end{array}$ \\
\hline $\mathrm{H} 3$ & $\begin{array}{l}\text { Entrepreneurship Education } \rightarrow \\
\text { Entrepreneurial Intention }\end{array}$ & 0.464 & 0.000 & $\begin{array}{l}\text { Positive, significant, } \\
\text { data does not support } \\
\text { the research model }\end{array}$ \\
\hline $\mathrm{H} 4$ & $\begin{array}{l}\text { Entrepreneurship Education } \rightarrow \\
\text { Entrepreneurial Orientation } \rightarrow \\
\text { Entrepreneurial Intention }\end{array}$ & 0.778 & 0.000 & $\begin{array}{l}\text { Positive, significant, } \\
\text { data supports the } \\
\text { research model }\end{array}$ \\
\hline
\end{tabular}

\subsection{The Effect of Entrepreneurship Education on Entrepreneurial Orientation}

Table 2 shows that Entrepreneurship Education has a positive influence on Entrepreneurial Orientation so that Hypothesis 1 is accepted with a coefficient value of 0.671 where the probability level is $0.000<0.05$.. This means that if the Entrepreneurship Education provided to students is further improved in quality, then students will have an Entrepreneurial Orientation. Students will be more honed in terms of innovation, creative thinking, and dare to take risks which are characteristics of entrepreneurs. There is an evaluation by the University (faculty) whether Entrepreneurship Education has been effective in forming Entrepreneurial Orientation for students to be able to become entrepreneurs. [41] in his findings supports that Entrepreneurship Education contributes positively in increasing entrepreneurial knowledge and Entrepreneurial Orientation to become entrepreneurs. The lecturers, who have a strategic role as a catalyst to encourage entrepreneurship in the surrounding environment, where lecturers at universities should be entrepreneurship oriented. ([13], [43], [44]. The government also designs programs for developing an entrepreneurial culture in universities such as the Student Creativity Program (PKM), seminars on successful young entrepreneurs, Entrepreneurship Internships (MKU) and the New Entrepreneurial Incubator (INWUB) where all of these activities can encourage students to be ready to start entrepreneurship, especially when they graduate from college [45].

\subsection{The Effect of Entrepreneurial Orientation on Entrepreneurial Intention}

The results showed that Entrepreneurial Orientation has a positive influence on Entrepreneurial Intention so that Hypothesis 2 is accepted with a coefficient value of 0.777 with a probability level of $0.000<0.05$. This means that the greater a person's entrepreneurial orientation, the higher a person's intention to become an entrepreneur. This is supported by 
[46] where there is a positive relationship between an individual's tolerance for risk and his intention to become an entrepreneur. In addition, there is also an Academic Program that directs graduates to be able to apply their technological knowledge and skills according to their disciplines.. This means that graduates are expected not only to become employees, but also to become job creators. For this reason, new students at Trisakti University since semester one (1) have grown Entrepreneurial Orientation. This is in accordance with research conducted by [24], [47] that Entrepreneurial Orientation is proven to positively grow Entrepreneurial Intention. In this case, government's support in the field of education is needed to design a comprehensive curriculum and benefits, so that universities can prepare and give birth to a generation of independent entrepreneurs.

\subsection{The Effect of Entrepreneurship Education on Entrepreneurial Intention}

However, Entrepreneurship Education has no effect on Entrepreneurial Intention, where the probability level is $0.326>0.05$ with a coefficient value of 0.464 so that Hypothesis 3 is rejected, meaning that Entrepreneurship Education is not enough to affect Entrepreneurial Intention. The results of this study are supported by (Agung, 2009) where there is ineffectiveness in the selection of learning materials and models. [48]found that entrepreneurship materials, seminars and workshops that have been given on campus do not necessarily foster Entrepreneurial Intention. The readiness of the right instrument is needed to facilitate the learning process as well as previous work experience. Meanwhile [49] stated that students in Norway prefer to be workers than to be entrepreneurs. [41] said the need for family support to grow Entrepreneurial Intention.

\subsection{Entrepreneurship Education has an indirect effect on Entrepreneurial Intention mediated by Entrepreneurial Orientation}

The results showed that there was an indirect effect of Entrepreneurship Education on Entrepreneurial Intention mediated by Entrepreneurial Orientation, so that hypothesis 4 was accepted with a coefficient value of 0.778 with a probability level of $0.000<0.05$. Entrepreneurial Orientation strengthens in mediating the influence of Entrepreneurship Education on Entrepreneurial Intention. In this case, Entrepreneurship Education will be effective in growing students' Entrepreneurial Intention, if Entrepreneurship Education can grow students' Entrepreneurial Orientation. This means that Entrepreneurial Orientation plays a very important role in mediating the influence of Entrepreneurship Education on Entrepreneurial Intention. This is in line with research conducted by [50], [51].

\section{Conclusion}

Based on the previous analysis, the conclusions that can be given in this study are: 1) Entrepreneurship Education aims to foster an entrepreneurial spirit, whose role is to teach students to practice theory and understand what entrepreneurship is, which will change student behavior in Entrepreneurial Orientation. 2) Entrepreneurial Orientation is expected to change student behavior to become more independent, creative, proactive towards business opportunities, dare to take risks and be more aggressive in competing. 3) However, there needs to be a curriculum development that emphasizes the formation of attitudes rather than 
skills to improve students' entrepreneurial abilities, which will foster Entrepreneurial Intention.

\section{Managerial Implications and Suggestion}

\section{a) Managerial Implications}

Some managerial implications that researchers can provide are: (1) it is necessary to improve the entrepreneurship culture environment to foster an entrepreneurial spirit among students. (2) students still need to be equipped with competitive entrepreneurship courses that combine theoretical, hands-on practice and experience together, and provide learning opportunities to be actively involved in real business, to meet the demands of students' needs from various fields of science. (3) to improve Entrepreneurial Student intention, participating students in creativity and innovation competitions in order to get new ideas and develop them into even better ideas, as well as learning models more on attitude formation such as success stories.

\section{b) Suggestions for Further Researchers}

The suggestions that can be given to further researchers in order to improve the limitations of this research are:

1. Further research can add variables in this study, such as experience, ethnicity and gender related to Entrepreneurship Learning activities and their interest in Entrepreneurship Orientation and Entrepreneurial Intentions.

2. Further researchers can increase the number of respondents to be studied by comparing between Faculties at Trisakti University

\section{Acknowledgments}

Special thanks go to Dr. Astri Rinanti, MT, Director of Research and Community Service Trisakti University and Dr. Yolanda Masnita Siagian, MM, Dean of Faculty of Economics and Business, Trisakti University, for their continuous guidance and support. Special thanks go to Dr. Jakaria, ME for his moral support. I would like to thanks my college student of Economics and Business Faculty Trisakti University who gave me support.

\section{References}

[1] S. C. Mat, S. M. Maat, and N. Mohd, "Identifying Factors that Affecting the Entrepreneurial Intention among Engineering Technology Students," Procedia - Soc. Behav. Sci., vol. 211, no. September, pp. 1016-1022, 2015, doi: 10.1016/j.sbspro.2015.11.135.

[2] S. . Khan, "Entrepreneurship Education in Pakistani Universities," Sch. Entrep. Bus. Univ. Essex Southend-on-Sea UK, pp. 0-22, 2008.

[3] Elebe and I. Micah, "Integrating entrepreneurship education in technical and vocational education (TVE) curriculum: A tool for sustainable self-reliance of Nigerian youth," $J$. Res. Educ. Soc., vol. 2, no. 1, pp. 55-60, 2011.

[4] S. Widayati, "Peningkatan Kualitas Pendidikan Kewirausahaan," J. Waspada FKIP 
UNDARIS 1, pp. 1-11, 2013.

[5] R. P. Singh, E. L. Knox, and M. E. S. Crump, “Opportunity recognition differences between black and white nascent entrepreneurs: A test of bhave's model," J. Dev. Entrep., vol. 13, no. 1, pp. 59-75, 2008, doi: 10.1142/S1084946708000855.

[6] M. M. Mars and M. B. Ginter, "Academic Innovation and Autonomy: An Exploration of Entrepreneurship Education Within American Community Colleges and the Academic Capitalist Context," Community Coll. Rev., vol. 40, no. 1, pp. 75-95, 2012, doi: $10.1177 / 0091552111436209$.

[7] P. Rahmawati, D. H. Suwarto, and M. L. Endarwati, "Technopreneurship Course Development Program,” pp. 1-16, 2010.

[8] O. S. Atieno and J. Kenyatta, "The Contribution Of Youth Enterprise Development Fund On Youth Empowerment In Kangundo Constituency, Machakos County The Contribution Of Youth Enterprise Development Fund On Youth Empowerment In Kangundo Constituency, Machakos County," Strateg. J. Bus. Chang. Manag., 2015.

[9] L. Collins, P. D. Hannon, and A. Smith, "Enacting entrepreneurial intent: The gaps between student needs and higher education capability," Educ. + Train., vol. 46, pp. 454-463, 2004, doi: 10.1108/00400910410569579.

[10] S. J. Arthur, R. D. Hisrich, and Á. Cabrera, "The importance of education in the entrepreneurial process: A world view," J. Small Bus. Enterp. Dev., vol. 19, no. 3, pp. 500-514, 2012, doi: 10.1108/14626001211250180.

[11] L. Pittaway and J. Cope, "Entrepreneurship education: A systematic review of the evidence," Int. Small Bus. J., vol. 25, no. 5, pp. 479-510, 2007, doi: 10.1177/0266242607080656.

[12] A. Fayolle, "Handbook of Research in Entrepreneurship Education: Volume 2," $J$. Enterprising Communities People Places Glob. Econ., vol. 2, no. 1, pp. 88-89, 2008, doi: 10.1108/17506200810861276.

[13] G. T. Lumpkin and G. G. Dess, "Clarifying the entrepreneurial orientation construct and linking it to performance," Acad. Manag. Rev., vol. 21, no. 1, pp. 135-172, 1996, doi: 10.5465/AMR.1996.9602161568.

[14] M. Jenkins and G. Johnson, "Entrepreneurial intentions and outcomes: A comparative causal mapping study,” J. Manag. Stud., vol. 34, no. 6, pp. 895-920, 1997, doi: 10.1111/1467-6486.00077.

[15] D. Miller, "The Correlates of Entrepreneurship in Three Types of Firms," Manage. Sci., vol. 29, no. 7, pp. 770-791, 1983, doi: 10.1287/mnsc.29.7.770.

[16] U. I. Ekpoh and A. O. Edet, "Entrepreneurship Education and Career Intentions of Tertiary Education Students in Akwa Ibom and Cross River States, Nigeria," Int. Educ. Stud., vol. 4, no. 1, pp. 172-178, 2011, doi: 10.5539/ies.v4n1p172.

[17] F. Izedonmi and C. Okafor, "Assesment of The Entrepreneurial Characteristics And Intentions Among Academics," IFE Psychol., vol. 2, no. Sept 2008, pp. 153-168, 2008.

[18] O. Y. Keat, C. Selvarajah, and D. Meyer, "Inclination towards entrepreneurship among university students : An empirical study of Malaysian university students," Int. J. Bus. Soc. Sci., vol. 2, no. July 2015, pp. 206-220, 2011, doi: 10.1016/j.egypro.2012.02.331.

[19] M. L. Harris and S. G. Gibson, "Examining the entrepreneurial attitudes of US business students," Educ. Train., vol. 50, no. 7, pp. 568-581, 2008, doi: 10.1108/00400910810909036.

[20] G. Packham, P. Jones, C. Miller, D. Pickernell, and B. Thomas, "Attitudes towards entrepreneurship education: A comparative analysis," Educ. + Train., vol. 52, no. 8-9, 
pp. 568-586, 2010, doi: 10.1108/00400911011088926.

[21] D. L. Bolton and M. D. Lane, "Individual entrepreneurial orientation: Development of a measurement instrument," Educ. Train., vol. 54, no. 2-3, pp. 219-233, 2012, doi: 10.1108/00400911211210314.

[22] K. H. Chen, J. M. Yien, K. P. Huang, and H. C. Jung, "Performance and its Link to Entrepreneurial Behavior,” Am. J. Appl. Sci., vol. 8, no. 7, pp. 703-707, 2011.

[23] D. Ketchen and J. Short, "Strategic Management," Strateg. Manag., 2002, doi: 10.1007/978-3-322-84457-6.

[24] Mustafa Baba, "Relationship Between Entrepreneurial Orientation , Entrepreneurial Education, Self-Efficacy and Entrepreneurial Intention Among Undergraduate Students At Nigerian Universities Master of Science," 2014.

[25] W. J. Wales, "Entrepreneurial orientation: A review and synthesis of promising research directions," Int. Small Bus. J. Res. Entrep., vol. 34, no. 1, pp. 3-15, 2016, doi: $10.1177 / 0266242615613840$.

[26] J. Erickson, S. Niranjan, V. Gupta, and B. Goktan, "Individual entrepreneurial orientation role in shaping reactions to new technologies," 2015 Am. Conf. Inf. Syst. AMCIS 2015, pp. 1-15, 2015.

[27] M. J. Mustafa, E. Hernandez, C. Mahon, and L. K. Chee, "Entrepreneurial intentions of university students in an emerging economy: The influence of university support and proactive personality on students' entrepreneurial intention," J. Entrep. Emerg. Econ., vol. 8, no. 2, pp. 162-179, 2016, doi: 10.1108/JEEE-10-2015-0058.

[28] J. C. Sánchez, "The impact of an entrepreneurship education program on entrepreneurial competencies and intention," J. Small Bus. Manag., vol. 51, no. 3, pp. 447-465, 2013, doi: 10.1111/jsbm.12025.

[29] J. Wiklund and D. Shepherd, "Entrepreneurial orientation and small business performance: A configurational approach,” J. Bus. Ventur., vol. 20, no. 1, pp. 71-91, 2005, doi: 10.1016/j.jbusvent.2004.01.001.

[30] D. T. Gerba, "The context of entrepreneurship education in Ethiopian universities," Manag. Res. Rev., vol. 35, no. 3-4, pp. 225-244, 2012, doi: 10.1108/01409171211210136.

[31] T. N. Garavan and B. O'Cinneide, "Entrepreneurship Education and Training Programmes: Literature review," J. Eur. Ind. Train., vol. 18, no. 8, pp. 3-12, 1994.

[32] C. Hegarty, "It's not an exact science: Teaching entrepreneurship in Northern Ireland," Educ. Train., vol. 48, no. 5, pp. 322-335, 2006, doi: 10.1108/00400910610677036.

[33] M. Gallant, S. Majumdar, and D. Varadarajan, "Outlook of female students towards entrepreneurship: An analysis of a selection of business students in Dubai," Educ. Bus. Soc. Contemp. Middle East. Issues, vol. 3, no. 3, pp. 218-230, 2010, doi: 10.1108/17537981011070127.

[34] R. L. Engle et al., "Entrepreneurial intent: A twelve-country evaluation of Ajzen's model of planned behavior," Team Perform. Manag., vol. 16, no. 1-2, pp. 35-57, 2010, doi: 10.1108/13552551011020063.

[35] B. Urban, J. J. Van Vuuren, and R. H. Owen, "Anticedents to entrepreneurial intentions: Testing for measurement invariance for cultural values, attitudes and selfefficacy beliefs across ethnic groups," SA J. Hum. Resour. Manag., vol. 6, no. 1, pp. 19, 2008, doi: 10.4102/sajhrm.v6i1.132.

[36] S. Choo and M. Wong, "Entrepreneurial intention: Triggers and barriers to new venture creations in Singapore," Singapore Manag. Rev., vol. 28, no. 2, pp. 47-64, 2006.

[37] B. R. Lestari and T. Wijaya, "Pengaruh Pendidikan Kewirausahaan Terhadap Minat 
Berwirausaha Mahasiswa di STIE MDP, STMIK MDP, dan STIE MUSI," Forum Bisnis dan Kewirausahaan J. Ilm. STIE MDP, no. October, 2012, doi: 10.31227/osf.io/kejft.

[38] J. Malebana, "Entrepreneurial intentions of South African rural university students: A test of the theory of planned behaviour," J. Econ. Behav. Stud., vol. 6, no. 2, pp. 130143, 2014, doi: 10.22610/jebs.v6i2.476.

[39] F. Alberti, S. Sciascia, and A. Poli, "Entrepreneurship Education : Notes on an Ongoing Debate," 14th Annu. IntEnt Conf., no. July, pp. 4-7, 2004.

[40] W.-L. Koe, "The relationship between Individual Entrepreneurial Orientation (IEO) and entrepreneurial intention," J. Glob. Entrep. Res., vol. 6, no. 1, 2016, doi: 10.1186/s40497-016-0057-8.

[41] C. Mwatsika, "Effect of Entrepreneurship Education on Students Orientation Towards Entrepreneurship at the Malawi Polytechnic," Int. J. Bus. Econ. Res., vol. 5, no. 6, p. 235, 2016, doi: 10.11648/j.ijber.20160506.17.

[42] U. Sekaran and R. Bougie, "Research Methods for Business," Wiley, vol. seven edit, pp. 1-447, 2016.

[43] S. M. Lee and S. Lim, "Entrepreneurial orientation and the performance of service business," Serv. Bus., vol. 3, no. 1, pp. 1-13, 2009, doi: 10.1007/s11628-008-0051-5.

[44] A. M. Moreno and J. C. Casillas, "Entrepreneurial orientation and growth of SMEs: A causal model," Entrep. Theory Pract., vol. 32, no. 3, pp. 507-528, 2008.

[45] I. Bilić, A. Prka, and G. Vidović, "How does education influence entrepreneurship orientation? case study of Croatia," How does Educ. Influ. Entrep. orientation? case study Croat., vol. 16, no. 1, pp. 115-128, 2011.

[46] G. Segal, D. Borgia, and J. Schoenfeld, "The motivation to become an entrepreneur," Int. J. Entrep. Behav. Res., vol. 11, no. 1, pp. 42-57, 2005, doi: $10.1108 / 13552550510580834$.

[47] A. Adegbuyi, O. Fadeyi, A. O. Oke, M. A. Ajagbe, and D. T. Isiavwe, "Sustainable Economic Growth and Poverty Reduction through Entrepreneurship," Int. J. Acad. Res. Econ. Manag. Sci., vol. 4, no. 2, pp. 62-75, 2015, doi: 10.6007/ijarems/v4-i2/1675.

[48] T. Nastiti, N. Indarti, and R. Rostiani, "Minat Berwirausaha Mahasiswa Indonesia Dan Cina," J. Manag. Bus., vol. 9, no. 2, pp. 187-200, 2010, doi: 10.24123/jmb.v9i2.164.

[49] N. Indarti and S. Kristiansen, "Determinants of The Case of Norwegian Students," Int. J. Bus., vol. 5, no. 1, pp. 79-95, 2003.

[50] I. Ekpe and N. Mat, "The Moderating Effect of Social Environment on the Relationship between Entrepreneurial Orientation and Entrepreneurial Intentions of Female Students at Nigerian Universities," SSRN Electron. J., no. June 2018, 2015, doi: 10.2139/ssrn.2701158.

[51] I. Martins and J. P. Perez, "Testing mediating effects of individual entrepreneurial orientation on the relation between close environmental factors and entrepreneurial intention," Int. J. Entrep. Behav. Res., vol. 26, no. 4, pp. 771-791, 2020, doi: 10.1108/IJEBR-08-2019-0505. 